\title{
KUALITAS HIDUP PASIEN KANKER YANG MENJALANI KEMOTERAPI DI BANDUNG CANCER SOCIATY
}

\section{LIFE QUALITY OF CANCER PATIENTS THROUGH CHEMOTHERAPY IN BANDUNG CANCER SOCIATY}

\author{
Sri Mulyati Rahayu ${ }^{1}$, Tuti Suprapti ${ }^{2}$ \\ ${ }^{1,2}$ Fakultas Keperawatan Universitas Bhakti Kencana \\ e-mail: sri.mulyati@bku.ac.id
}

\begin{abstract}
ABSTRAK
Kanker merupakan masalah kesehatan di seluruh dunia dan diproyeksikan angka morbiditas akan terus meningkat $70 \%$ pada tahun 2030. Kemoterapi merupakan salah satu teknik pengobatan kanker yang berdampak terhadap kondisi fisiologis, dan psikologis, sehingga berpengaruh pada kualitas hidup pasien. Tujuan penelitian untuk mengetahui kualitas hidup pasien kanker yang menjalani kemoterapi. Metode penelitian adalah deskriptif. Populasi dalam penelitian ini adalah pasien kanker di Bandung Cancer Society (BCS) dengan jumlah sampel 30 orang. Teknik sampling menggunakan quota sampling, dengan karakteristik sampling semua pasien kanker yang menjalani kemoterapi yang rutin datang ke BCS yang berespon terhadap peneliti saat pengumpulan data sampai berjumlah 30 orang. Intrument yang digunakan untuk mengukur kualitas hidup dengan intrumen baku EOTC QLQ C-30. Intrument tersebut mengelompokkan menjadi 3 skala, yaitu skala fungsional, skala gejala, dan skala kesehatan secara umum. Hasil penelitian kualitas hidup pasien kanker yang menjalani kemoterapi adalah skala fungsional katagori baik, skala gejala katagori buruk, dan skala kesehatan secara umum katagori sedang. Kesimpulan kualitas hidup pasien kanker yang menjalani kemoterapi berada pada katarori sedang $(614,55)$, sehingga disarankan perlunya informasi yang diberikan secara terus menerus kepada pasien terkait kondisi yang akan dialami selama menjalani kemoterapi.
\end{abstract}

Keyword: Kualitas Hidup, , Kemoterapi, Penderita Kanker

\begin{abstract}
Cancer is a health problem worldwide and it is projected that the morbidity rate will continue to increase by $70 \%$ by 2030 . Chemotherapy is a cancer treatment technique that has an impact on physiological and psychological conditions, thus affecting the quality of life of patients. The research objective was to determine the quality of life of cancer patients undergoing chemotherapy. The research method is descriptive. The population in this study were cancer patients at the Bandung Cancer Society with a total sample of 30 people. The sampling technique uses quota sampling ,. The instrument used to measure the quality of life with the EOTC QLQ C-30 standard instrument. The instrument is grouped into 3 scales, namely the functional scale, the symptom scale, and the general health scale. The results of the research on the quality of life of cancer patients who underwent chemotherapy were a functional scale for a good category, a symptom scale for a bad category, and a scale for general health in a moderate category. The conclusion is that the quality of life of cancer patients undergoing chemotherapy is in the moderate category $(614,55)$, so it is suggested that information be given continuously to patients regarding the conditions they will experient
\end{abstract}

Keyword: Quality of Life, Chemotherapy, Cancer Patients 


\section{PENDAHULUAN}

Kanker merupakan keganasan yang terjadi pada sel dan jaringan tubuh. Pengobatan yang berlangsung lama memiliki efek kesakitan tinggi, membawa dalam kondisi lemah bahkan depresi. Penderitaan tersebut berpengaruh pada kualitas hidup pasien. Kualitas hidup adalah persepsi individu mengenai keadaan dirinya pada aspekaspek kehidupan untuk mencapai kepuasan hidup ${ }^{1}$.

Menurut Riskesdas 2018 angka kejadian kanker mengalami kenaikan dari tahun 2013, yaitu 1,4 menjadi $1,8^{2}$. Evaluasi kualitas hidup pada pasien kanker sering dijadikan acuan keberhasilan dari suatu terapi dan peningkatan kontribusi pada pengobatan yang lebih baik. Pengukuran kualitas hidup dapat mempengaruhi pengambilan keputusan terapi. Hasil penelitian didapatkan kualitas hidup pasien kanker payudara yang menjalani kemoterapi, dilihat dari skala fungsional termasuk katagori sedang $(62,44 \pm 16,59)$, skala gejala termasuk katagori sedang $(62,44 \pm 16,59)$, dan status kesehatan umum katagori sedang $(65,03 \pm 14,831)^{3}$.

Pasien kanker yang menjalani kemoterapi memiliki dampak secara fisiologis maupun psikologis seperti rasa lelah, lesu, kerontokan rambut, gangguan usus, rongga mulut, sumsum tulang belakang, kemandulan, menstruasi dan menopause, kesedihan, kekhawatiran, ketakutan akan masa depan dan kematian ${ }^{4,5}$.

Pelayanan paliatif hendaknya diberikan sejak awal perjalanan penyakit. Masalah yang berbeda terkait dengan perbedaan latar belakang budaya, nilai personal, dan ekonomi, sehingga penting untuk mengkaji masalah dan kebutuhan pasien yang dapat diberikan sesuai dengan kebutuhan dalam upaya meningkatkan kualitas hidup ${ }^{5}$. Kualitas hidup pasien kanker dipengaruhi oleh pendidikan, usia, pekerjaan, pendapatan, status pernikahan, stadium kanker, komunikasi, system nilai, dan dukungan keluarga ${ }^{6}$.

Bandung Cancer Sosiety (BCS) merupakan rumah singgah kerjasama dengan pemprov Jabar yang diperuntukkan bagi pasien kanker yang akan menjalani kemoterapi, bisa berasal dari Bandung ataupun luar Bandung. Sebelum pandemi covid-19 rumah singgah ini selalu penuh oleh pasien yang akan menjalani kemoterapi. Pasien yang datang ke rumah singgah BCS selalu mendapat informasi terkait masalah yang dihadapi selama menjalani kemoterapi dan penatalaksanaannya, tetapi semenjak pandemi Covid-19 rumah singgah tidak menerima pasien, karena resiko tinggi bagi pasien kanker yang termasuk kormobid, jika ada yang meninggal menjadi ketakutan untuk masyarakat yang ada di sekitar rumah singgah tersebut. Sehingga pemantauan kualitas hidup menjadi sulit diketahui. Penelitian ini bertujuan untuk mengetahui kualitas hidup pada pasien kanker yang menjalani kemoterapi.

\section{METODE}

Metode yang digunakan adalah deskriptif. Variabel penelitian adalah kualitas hidup pasien kanker yang menjalani kemoterapi. Populasi dalam penelitian ini adalah pasien kanker di Bandung Cancer Society dengan jumlah sampel 30 pasien Teknik sampling dengan menggunakan kuota sampling selama 1 minggu. Pengumpulan data dengan cara video call/telpon pasien melalui Whattapp yang dibantu oleh enumerator pengelula BCS. Intrumen untuk menilai kualitas hidup dengan intrument baku EOTC QLQ C-30 berisi 30 pertanyaan mengenai kualitas hidup khusus 
pasien kanker. Terjemahan dan validasi EORTC-QLQ-C30 ke dalam versi Indonesia untuk pasien kanker di Indonesia dilakukan oleh Perwitasari et al (2011) ${ }^{6}$.

Hasil Uji validitas dengan STATA® versi 12 didapatkan nilai > 0,7 artinya semua butir pertanyaan adalah valid dan nilai $\alpha$ $>0,50$ berarti bahwa seluruh item pertanyaan dalam kuesioner EORTC QLQ C30 adalah reliabel ${ }^{7}$. Cara menghitung skor kualitas hidup dengan menggunakan kuesioner EORTC QLQ C-30 terdiri dari dua tahap, yaitu tahap menghitung raw score dan tahap transformasi linear. Tahap menghitung raw score menggunakan rumus berikut:

Raw Score $=\mathrm{RS}=(\mathrm{I} 1+\mathrm{I} 2+\mathrm{I} 3+\ldots . \mathrm{In}) / \mathrm{n}$ dengan $\mathrm{I}=$ nilai untuk tiap item pertanyaan dan $n=$ jumlah item pertanyaan ${ }^{8}$.

Tahap transformasi linear dilakukan untuk menstandarkan raw score sehingga rentang skor menjadi antara0-100. Terdapat tiga kelompok skala, yaitu skala fungsional, skala gejala dan status kesehatan global. Setiap item pertanyaan dapat dijawab dengan memilih poin $1=$ tidak, 2 = sedikit, $3=$ sering, atau $4=$ sangat sering, yang kemudian ditransformasikan kedalam rentang nilai 0-100. Interpretasi per-item soal dapat dilihat pada tabel $1^{8,9}$.

\section{Tabel 1}

\section{Interpretasi kualitas hidup per-item soal}

\begin{tabular}{ll}
\hline Skor & Interpretasi \\
\hline$\leq 33,3$ & Buruk \\
$33,4-66,5$ & Sedang \\
$>66,6$ & Baik \\
\hline
\end{tabular}

Skor yang lebih tinggi merepresentasikan

level yang lebih baik untuk fungsional atau lebih buruk untuk gejala.

Tabel 2

Transformasi Linear untuk Memperoleh Skor

\begin{tabular}{ll}
\hline Skala & Transformasi Linear \\
\hline Fungsional & $\mathrm{S}=[1-(\mathrm{RS}-$ \\
\hline
\end{tabular}

\begin{tabular}{ll}
\hline Gejala & 1)/rentang) $]$ x 100 \\
& $\mathrm{~S}=[(\mathrm{RS}-1) /$ rentang $]$ \\
x 100 \\
$\begin{array}{l}\text { Ktatus } \\
\text { Kesehatan }\end{array}$ & $\mathrm{S}=[(\mathrm{RS}-1) /$ rentang $]$ \\
Global & \\
\hline
\end{tabular}

Interpretasi skor kualitas hidup dapat dilihat pada Tabel $3{ }^{10}$.

Tabel 3

Skor Interpretasi Kualitas Hidup

\begin{tabular}{ll}
\hline Skor & Interpretasi \\
\hline$<500$ & Buruk \\
$501-1000$ & Sedang \\
$>1000$ & Baik \\
\hline
\end{tabular}

\section{HASIL}

Hasil penelitian kualitas hidup ditampilkan dalam bentuk tabel dengan menilai per-item kualitas hidup dalam setiap skala. Selanjutnya dikelompokkan menjadi 3 skala, yaitu skala fungsional, skala gejala dan skala Kesehatan umum. Hasil rata-rata skor skala fungsional 89,73 termasuk katagori baik, skor rata-rata skala gejala 12,83 termasuk katagori buruk, dan skor rata-rata skala kesehatan secara umum 38 termasuk katagori sedang. Penilaian dari ke-3 skala digabungkan menjadi nilai kualitas hidup, yaitu 614,55 termasuk katagori sedang. Lebih jelas bisa dilihat di tabel 5.

Tabel 4

Distribusi frekwensi karakteristik pasien kanker yang menjalani kemoterapi di Bandung Cancer Society

\begin{tabular}{lllc}
\hline No & $\begin{array}{l}\text { Usia } \\
\text { (tahun) }\end{array}$ & Jumlah & $\begin{array}{l}\text { Prosentase } \\
(\%)\end{array}$ \\
\hline 1 & $17-25$ & 1 & 3,33 \\
\hline 2 & $26-35$ & 0 & 0 \\
\hline 3 & $36-45$ & 7 & 23,33 \\
4 & $46-55$ & 13 & 43,34 \\
\hline 5 & $56-65$ & 8 & 26,67 \\
\hline 6 & $\boldsymbol{D} 65$ & 1 & 3,33 \\
& Total & 30 & 100 \\
\hline
\end{tabular}


Tabel 5

\section{Kualitas Hidup pada Pasien Kanker yang sedang Menjalani Kemoterapi di Bandung Cancer Society}

\begin{tabular}{|c|c|c|c|}
\hline Kelompok & $\begin{array}{l}\text { Jenis } \\
\text { Pengukuran }\end{array}$ & Skor & Katagori \\
\hline \multirow[t]{7}{*}{$\begin{array}{l}\text { Skala } \\
\text { Fungsional }\end{array}$} & $\begin{array}{l}\text { Fungsi Fisik } \\
(1-5)\end{array}$ & 89,76 & Baik \\
\hline & $\begin{array}{l}\text { Fungsi peran } \\
(6,7)\end{array}$ & 95,00 & Baik \\
\hline & $\begin{array}{l}\text { Fungsi } \\
\text { emosional } \\
(21-24)\end{array}$ & 86,67 & Baik \\
\hline & $\begin{array}{l}\text { Fungsi } \\
\text { kognitif } \\
(20,25)\end{array}$ & 85,00 & Baik \\
\hline & $\begin{array}{l}\text { Fungsi sosial } \\
(26,27)\end{array}$ & 92,23 & Baik \\
\hline & $\begin{array}{l}\text { Total Skor } \\
\text { skala } \\
\text { Fungsional }\end{array}$ & 448,67 & \\
\hline & $\begin{array}{l}\text { Rata-rata } \\
\text { Skor } \\
\text { Fungsional }\end{array}$ & 89,73 & Baik \\
\hline \multirow[t]{9}{*}{$\begin{array}{l}\text { Skala } \\
\text { Gejala }\end{array}$} & $\begin{array}{l}\text { Kelelahan } \\
(10,12,18)\end{array}$ & 17,03 & Buruk \\
\hline & $\begin{array}{l}\text { mual muntah } \\
(14,15)\end{array}$ & 5,57 & Buruk \\
\hline & Nyeri $(9,19)$ & 13,9 & Buruk \\
\hline & Dispneu (8) & 4,44 & Buruk \\
\hline & $\begin{array}{l}\text { insomnia } \\
\text { (11) }\end{array}$ & 14,44 & Buruk \\
\hline & $\begin{array}{l}\text { appetite lose } \\
\text { (13) }\end{array}$ & 6,67 & Buruk \\
\hline & $\begin{array}{l}\text { konstipasi } \\
\text { (16) }\end{array}$ & $\mathbf{3 , 3 3}$ & Buruk \\
\hline & $\begin{array}{l}\text { Total Skor } \\
\text { Skala Gejala }\end{array}$ & 89,83 & \\
\hline & $\begin{array}{l}\text { Rata-rata } \\
\text { Skor skala } \\
\text { Gejala }\end{array}$ & 12,83 & Buruk \\
\hline \multirow[t]{4}{*}{$\begin{array}{l}\text { Skala } \\
\text { Kesehatan } \\
\text { Umum }\end{array}$} & $\begin{array}{l}\text { Status } \\
\text { Kesehatan } \\
\text { Global }\end{array}$ & 38,8 & Sedang \\
\hline & & 37,2 & Sedang \\
\hline & $\begin{array}{l}\text { Skor } \\
\text { Kesehatan } \\
\text { Umum }\end{array}$ & 76,0 & Sedang \\
\hline & $\begin{array}{l}\text { Rata-rata } \\
\text { skor skala } \\
\text { Kesehatan } \\
\text { umum }\end{array}$ & 38 & Sedang \\
\hline $\begin{array}{l}\text { Kualitas } \\
\text { Hidup }\end{array}$ & $\begin{array}{l}\text { Skor Total } \\
\text { Kualitas } \\
\text { Hidup }\end{array}$ & 614,55 & Sedang \\
\hline
\end{tabular}

\section{PEMBAHASAN}

Berdasarkan tabel 4 hampir setengahnya $(43,34 \%)$ responden berusia antara 46-55 termasuk lanjut usia awal. Pada masa lanjut usia, seseorang akan mengalami perubahan dalam segi fisik, kognitif, maupun dalam kehidupan psikososialnya. Lansia secara umum jika digambarkan memang kurang menggembirakan, seperti Usia tua, kesepian, sosial ekonomi yang kurang sejahtera, serta munculnya penyakit-penyakit degeneratif seperti kanker, jantung, reumatik, serta katarak menyebabkan produktivitas menurun serta mempengaruhi kehidupan sosial ${ }^{6}$.

Pasien kanker yang menjalani kemoterapi dalam usia lansia awal sangat berdampak terhadap kualitas hidup lansia tersebut. Pada tabel 5 tampak kualitas hidup pasien kanker yang menjalani kemoterapi dengan menggunakan kuisioner EORTC QLQ-C30 memiliki skor 614,55. Jika melihat skor kualitas hidup termasuk katagori sedang artinya penilaian dari 3 skala, yaitu skala fungsional, skala gejala dan skala kesehatan umum ada yang sudah baik, sedang ataupun masih buruk. Hal ini bisa dilihat per-skala yang dinilai. Tampak nilai skala fungsional dengan rata-rata skor 89,73 termasuk katagori baik. Kemungkinan memiliki nilai kualitas hidup dari skala fungsional baik, karena pasien kemoterapi yang datang ke rumah singgah, sering mendapatkan informasi terkait menjaga kesehatan, dan support dari sesama penderita kanker juga pengurus yang juga mengalami kanker yang memiliki kualitas hidup yang baik. Support sistem yang kuat dari lingkungan dapat meningkatkan imunitas, sehingga pasien kanker menjadi kuat. Domain nilai tertinggi pada fungsi peran $(95,00)$ artinya pasien kanker yang menjalani kemoterapi ini masih dapat melaksanakan perannya baik sebagai istri maupun sebagai ibu dari anak-anaknya. Responden selesai menjalani kemoterapi biasanya pulang kembali ke rumahnya masingmasing dan masih bisa berperan dengan baik sebagai istri dan sebagai seorang ibu. 
Hasil skala fungsional sama dengan penelitian Juwita (2019) termasuk katagori sedang, namun berbeda dalam domain nilai skala fungsional. Penelitian Juwita memiliki domain tertinggi pada kognitif tentang kemampuan mengingat dan kamampuan berkonsentrasi. Responden umumnya menyatakan tidak terlalu merasakan adanya perubahan pada pola pikir mereka dalam kemampuan mengingat dan berkonsentrasi responden masih cukup baik setelah menjalani kemoterapi.

Penelitian Juwita tidak menampilkan usia dari responden, sehingga tidak bisa diketahui skala kognitifnya dipengaruhi oleh usia atau tidak, sedangkan pada responden penelitian ini, kemungkinan domain skala fungsional bukan kognitif, karena secara mayoritas respondennya termasuk usia lanjut yang secara fisiologis ada penurunan kemampuan kognitif. Sedangkan nilai skala gejala rata-rata skor gejala 12,83 termasuk buruk. Hal ini menunjukkan dampak gejala penderita kanker yang menjalani kemoterapi, seperti cepat Lelah, mual, muntah, nyeri, dispneu, insomnia, hilang nafsu makan, dan konstipasi sulit untuk dihindari. Hal ini yang perlu diinformasikan kepada penderita kanker yang sedang menjalani kemoterapi agar memiliki semangat, sehingga gejala yang muncul sebagai dampak kemoterapi tidak dirasakan berlebihan yang bisa menimbulkan rasa tidak berdaya dan tidak memiliki semangat untuk bertahan hidup.

Pada penelitian ini domain nilai tertinggi pada skala gejala adalah kelelahan $(17,03)$. Hal ini menunjukkan kondisi terburuk dari skala gejala pada respomden adalah merasa kelelahan. Hal ini bisa terjadi karena mayoritas pasien yang datang ke rumah singgah BCS dari luar Bandung, tetapi masih lingkup Jawa Barat, seperti Cianjur, Sukabumi, ataupun di Bandung tetapi lokasi rumahnya jauh dari RS tempat dilakukan kemoterapi. Selain itu kemungkinan kelelahan karena responden setelah di rumah harus kembali melaksanakan perannya sebagai ibu ataupun istri. Sedangkan hasil ini berbeda kembali dengan hasil penelitian Juwita, yaitu skala gejala termasuk katagori sedang $(68,00 \pm$ $28,82)$ dengan domain tertinggi pada mual dan muntah dilanjutkan dengan domain berikutnya kelelahan. Mual dan muntah akibat kemoterapi secara umum dinilai sebagai efek samping paling tidak menyenangkan pada pasien yang menjalani kemoterapi yang menyebabkan penurunan kualitas hidup.

Hasil nilai rata-rata skor kesehatan secara umum antara penelitian ini $(38,00)$ dan Juwita $(65,03 \pm 14,831)$ sama-sama termasuk katagori sedang, karena kualitas hidup responden yang sangat dipengaruhi oleh skala fungsional dan skala gejala. Pasien tidak akan mengalami penurunan yang signifi kan pada status kesehatan umum jika sebelumnya telah menerima informasi mengenai apa yang akan dihadapi selama mendapatkan kemoterapi.

Hasil penelitian kualitas hidup pasien yang menjalani kemoterapi di BCS termasuk katagori sedang (614,55). Penilaian ini sangat dipengaruhi oleh tiga penilaian skala, yaitu skala fungsional, skala gejala, dan skala kesehatan umum yang telah dijelaskan di atas.

\section{KESIMPULAN}

Kualitas hidup pasien kanker yang menjalani kemoterapi di Bandung Cancer Society termasuk katagori sedang, yang terdiri dari skala fungsional katagori baik, skala gejala katagori buruk, dan skala kesehatan secara umum katagori sedang.

\section{DAFTAR PUSTAKA}

1. Prastiwi Tita Febri. 2012. Kualitas hidup penderita Unnes.ac.id/sju/indexphp/dep

2. Kementrian Kesehatan Badan Penelitan dan Pengenbangan Kesehatan. 2018. Hasil Utama Riskesdas 2018

3. Juwita Dian A., Almahdy, Afdila R. 2019. Penilaian Kualitas Hidup Terkait Kesehatan Pasien Kanker Payudara di RSUP Dr. M. Djamil Padang, Indonesia. Jurnal Ilmu Kefarmasian Indonesia, April 2019, hlm. 114-119 Vol. 17, No. 1 EISSN: 2614-6495 
4. Pratiwi, S. R., Widianti, E., \& Solehati, T. (2017). Gambaran faktor-faktor yang berhubungan dengan kecemasan pasien kanker payudara dalam menjalani kemoterapi. Jurnal Pendidikan Keperawatan Indonesia, 3(2), 167-174.

5. Natasya, M. (2017). Gambaran Kualitas Hidup Pasien Kanker Payudara dengan Perawatan Paliatif oleh Garwita Institute

6. Rohmah Anis Ika Nur , Purwaningsih , KhoridatulBariyah.(2012). Kualitas Hidup Lanjut Usia. Jurnal Keperawatan. Voume 3 No. 2. hal. 120-132. ISSN 2086-3071

7. Rini Noviyani, Ketut Tunas, Ayu Indrayathi, Nyoman G. Budiana. 2016. Uji Validitas dan Reliabilitas Kuesioner EORTC QLQ C30 untuk Menilai Kualitas Hidup Pasien Kanker Ginekologi di RSUP Sanglah Denpasar. Vol. 5 No. 2, hlm 106-114. ISSN: 2252-6218. Jurnal Farmasi Klinik Indonesia, Juni 2016

8. Effendy, C. (2014). Pengembangan manajemen pelayanan paliatif. Jurnal Manajemen Pelayanan Kesehatan, 17(1).

9. Irawan, E., Rahayuwati, L., \& Yani, D. I. (2017). Hubungan penggunaan terapi modern dan komplementer terhadap kualitas hidup pasien kanker payudara. Jurnal Keperawatan Padjadjaran, 5(1)

10. Tan ML, Idris DB, Teo LW, Loh SY, Seow GC, ChiaYY, Tin AS. Validation of EORTC QLQ-C30 and QLQBR23 questionnaires in the measurement of quality of life of breast cancer patients in Singapore. Asia-Pasifi c Journal of Oncology Nursing. 2014.1(1):22 32. 